\title{
GALAMBOS V PEREZ, ITS CRITICS, AND THE EQUITY- CERTAINTY PARADOX IN FIDUCIARY LAW
}

\author{
Calvin DeWolfe*
}

\section{INTRODUCTION}

In the legal context, certainty and equity are often perceived as opposite concepts. The academic commentary on fiduciary law, perhaps Canada's most controversial area of jurisprudence, embodies that perception. This paper rejects it: by analyzing and juxtaposing two popular critiques of Canada's leading fiduciary law decision, Galambos $v$ Perez, ${ }^{1}$ I will argue that ostensibly opposite legal principles can function best when combined.

Canadian law once defined fiduciary relationships ${ }^{2}$ according to categories. When a court questioned whether a particular relationship was fiduciary, its analysis primarily involved cross-referencing the relationship at hand against a list of per se relationships that were generally understood to be fiduciary in nature. ${ }^{3}$ In 1984, the Supreme Court of Canada's Guerin decision shifted the jurisprudence. Here, the Court recognized the relationship between the Crown and Canada's Indigenous peoples as fiduciary after emphatically stating that "it is the nature of the relationship, not the specific category of actor involved that gives rise to the fiduciary duty." "Three years later, in Frame $v$ Smith, ${ }^{5}$ Justice Wilson gave structure to the Court's newfound ad hoc approach by enumerating

Copyright $(02021$ by Calvin DeWolfe.

* Calvin DeWolfe holds a BA in Philosophy and is a recent graduate of Dalhousie's Schulich School of Law. After articling at the law firm Stewart McKelvey in Halifax, Nova Scotia, he intends to pursue a practice in commercial litigation and administrative law. Calvin wishes to acknowledge the helpful comments of Kim Brooks on an earlier version of this paper as well as the mentorship and advice of Steven Baldner and Doug Al-Maini.

${ }^{1} 2009$ SCC 48 [Galambos].

${ }^{2}$ This paper uses the term "fiduciary relationship" to refer to a particular set of interactions between one individual (the "fiduciary") and another individual (the "beneficiary"), which, according to fiduciary law, must be conducted in the best interest of the beneficiary, without regard to the self-interest of the fiduciary. It is well-established that fiduciary interactions do not always encompass every interaction between a fiduciary and a beneficiary, however. In this sense, the term "relationship" is not strictly accurate but is used in this paper for simplicity. See e.g. Guerin v Canada, [1984] 2 SCR 335 [Guerin].

${ }^{3}$ Classic per se fiduciary relationships include solicitor-client, doctor-patient, and trustee-beneficiary.

${ }^{4}$ Guerin, supra note 2 at 384.

${ }^{5}$ Frame v Smith, [1987] 2 SCR 99, [1987] SCJ No 49 (QL) [Frame]. 
specific indicia of the fiduciary concept. The indicia-based approach was intended to allow Canadian courts to impute fiduciary duties in one-off situations, but it took decades of back-and-forth split decisions for the Court to unanimously decide on a set of indicia. Finally, in Galambos, a neat two-indicia set was agreed upon: discretionary power of the fiduciary to affect the legal or vital practical interests of the beneficiary, and an undertaking of loyalty from the fiduciary. ${ }^{6}$

The Supreme Court of Canada's unanimity has been unsuccessful in silencing the critics who fundamentally disagree with the ad hoc, indicia-based approach. For example, Anthony Duggan has criticized the uncertainty and inefficiency of the ad hoc approach and called for fiduciary principles to be harmonized with the consent-based tenets of contract law. ${ }^{7}$ Meanwhile, Leonard Rotman has criticized the ad hoc approach for hamstringing the once free-floating function of equity in an ill-conceived search for concrete rules and tests. ${ }^{8}$ In short, Duggan argues that the application of fiduciary law must be made more certain, whereas Rotman argues that it must be made more flexible.

The contention of this paper is that fiduciary law needs a balance of certainty and flexibility. Certainty at too great a cost to flexibility betrays the equitable function of fiduciary law; however, in the efficiency-driven modern landscape, moulded by an economy rife with subtly power-dependent relationships, inconsistent and unpredictable results create unfairness which betrays the spirit of equity itself. After decades of split decisions from the Supreme Court of Canada, consistency has bred results. Galambos is a sound resting point for a once-turbulent jurisprudence.

\footnotetext{
${ }^{6}$ Galambos, supra note 1 at paras 66, 84-85.

${ }^{7}$ See e.g. Anthony Duggan, "Contracts, Fiduciaries and the Primacy of the Deal" in Elise Bant \& Matthew Harding, eds, Exploring Private Law (Cambridge: Cambridge University Press, 2010) at 278-79 [Duggan, "Primacy of the Deal"]; Anthony Duggan, "Fiduciary Obligations in the Supreme Court of Canada: A Retrospective" (2011) 50 Can Bus LJ 453 [Duggan, "Fiduciary Obligations"].

${ }^{8}$ See e.g. Leonard I Rotman, "The Fiduciary Concept and the Subjective Nature of Legal Certainty" (2008) 110:2 R du N 359; Leonard I Rotman, "The Fusion of Law and Equity: A Canadian Perspective on the Substantive, Jurisdictional, or Non-Fusion or Legal Equitable Matters" (2016) 2:2 CJCCL 497 [Rotman, "Fusion of Law and Equity"]; Leonard I Rotman, "Justice Cromwell and Fiduciary Duties: Placing Law into Context" (2017) 80:2 SCLR 263 [Rotman, "Placing Law into Context"]; Leonard I Rotman, "Understanding Fiduciary Duties and Relationship Fiduciarity" (2017) 62:4 McGill LJ 975 [Rotman, "Understanding Fiduciary Duties"]; Tamar Frankel, "Fiduciary Law” (1983) 71:3 Cal L Rev 795.
} 


\section{HISTORICAL AND CURRENT TREATMENTS OF EQUITY, CERTAINTY, AND THE AD HOC APPROACH}

The Supreme Court of Canada has wrestled with the ad hoc approach for 20 years, trying to articulate a set of indicia that best serve the fiduciary concept and its equitable origins in the modern context. A brief illustration of the fiduciary concept and an account of the Supreme Court's insights, failures, and successes in capturing the concept is helpful for understanding Duggan's and Rotman's respective arguments and my own arguments in response.

\section{i. The History of Equity and the Foundation of the Fiduciary Concept}

The fiduciary concept is a product of the Court of Chancery, an English court of equitable jurisdiction, which existed independently from common law courts from the fourteenth to nineteenth centuries. "Equity" remains a commonplace legal term today, but formal definitions often include reference to the Court of Chancery or courts of equity and are therefore unhelpful in the modern context. ${ }^{9}$ Aristotle was one of the first (and in some respects, one of the last) to provide a robust, substantive definition of equity itself. He juxtaposed equity and common law by writing that "[e]quity ... is superior to one sort of Justice (namely to strict Common Law Justice), but remains itself just ... [equity and strict Common Law Justice] are, in other words, neither absolutely identical nor generically different, that is, different in genus." ${ }^{10}$ Aristotle recognized that common law justice, insofar as it is necessarily formulated as a set of rules, will often only approximate morality, whereas equity is much closer to morality or fairness itself. In Aristotle's view, equity's role was to be a moral alternative to bend the common law back into shape when it became unfair or immoral.

The Court of Chancery, guided by an Aristotelian conception of equity, decided to take a flexible, individualized approach to particular cases that, judged under the rigid common law, would produce fundamentally unfair results. ${ }^{11}$ In Dudley v Dudley, ${ }^{12}$ an

\footnotetext{
${ }^{9}$ Black's Law Dictionary defines "Equitable Rule", for instance, as "a rule that is issued by a court of equity that is just and fair": Brian A Garner, Black's Law Dictionary, 5th ed (Toronto: Thomson Reuters, 2016) sub verbo "Equitable Rule".

${ }^{10}$ Anton-Hermann Chroust, “Aristotle's Conception of Equity” (1942) 18:2 Notre Dame L Rev 119 at 121.

${ }^{11}$ William Searle Holdsworth, "The Relation of the Equity Administered by the Common Law Judges to the Equity Administered by the Chancellor" (1916) 26:1 Yale LJ 1 at 22.

${ }^{12}$ Dudley v Dudley (1705), 24 ER 118 (Ch).
} 
early eighteenth-century dispute, the Chancery attempted to functionally define the equitable concept that it had become accustomed to using. It declared that equity "assists the law where it is defective and weak ... and defends the law from craft evasions, delusions, and new subtleties invented and contrived to evade and delude the common law". ${ }^{13}$ Crucially, the Chancery did not tether the definition of equity to any specific aspect of the common law. A centuries-old institution by this time, the Court seemed to recognize that a given area of the common law could at one point be weak (and need equity to supplement it) and later, after development, be strong (and no longer need the assistance of equity).

Despite its well-intentioned purpose and ostensible proficiency with equitable concepts, the Court of Chancery was commonly criticized. Charles Dickens was one of its foremost critics. His famous novel, Bleak House, ${ }^{14}$ tells the story of a family who waits in vain to inherit rightfully owed money from a disputed fortune. It criticizes the Chancery for being inefficient and unpredictable compared to common law courts. ${ }^{15}$ John Selden, a well-known English jurist, famously echoed Dickens by wryly commenting that any two Chancellors tend to have conceptions of justice as varied as the measurements of their feet. ${ }^{16}$ An important, if trite, take-away from these criticisms is that, while the unsuccessful party in a Court of Chancery case may have viewed the Court as "inefficient" or "unpredictable", the Chancery was only responsible for that inefficiency when it unnecessarily altered a functioning common law concept with an equitable doctrine. If the common law was truly defective and needed equity to make it just, then while equity may have been a proximate cause, the common law was primarily responsible for any delays or unpredictability. Ultimately, equity's flaw is not uncertainty itself, but over-intervention causing uncertainty.

The high-water mark for the Court of Chancery's use of equity was perhaps Keech $v$ Sanford,${ }^{17}$ which many scholars regard as the first case in the modern Anglo-American jurisprudence to substantively illustrate fiduciary principles. In this case, the rights to a

\footnotetext{
${ }^{13}$ Ibid at 119 (Ch).

${ }^{14}$ Charles Dickens, Bleak House, N Page, ed (Middlesex: Penguin, 1984).

${ }^{15}$ Ibid at 51.

${ }^{16}$ Sir F Pollock, ed, Table Talk of John Seldon, (London: Quaritch, 1927) at 43.

${ }^{17}$ Keech v Sandford (1726), Sel Cas Ch 61, 25 ER 223 (Ch) [Keech].
} 
market in Romford, England were vested in trust for an infant. The trustee tried to renew the rights in favour of the infant, but the lessor refused. The trustee then renewed the lease for himself at the expense of the infant beneficiary. An action was brought before the Court of Chancery. The Court held that the nature of the trustee's relationship with the beneficiary prohibited him from personally obtaining the benefit of the lease. The Court reasoned that in a trustee-beneficiary relationship the trustee must act in the best interests of the beneficiary. The Court therefore established that fiduciary duties are not premised upon the demonstration of actual fraud, but the mere potential for fraud. ${ }^{18}$ The fiduciary duty was born.

\section{ii. Certainty, Equity, and the Advent of the Ad Hoc Approach}

In 1984, a century after the Judicature Acts merged the legal and equitable jurisdictions of England, ${ }^{19}$ the Supreme Court of Canada decided Guerin and began a near 30-year struggle with balancing principles of equity and certainty. In this case, William Guerin, an Indigenous counsellor, brought an action alleging breach of fiduciary duty against the federal government for under-delivering on benefits it had promised to his Band in exchange for land. Justice Dickson (as he then was), writing for the majority, was forced to look beyond the traditional categories of fiduciary relationships to find a duty. He surveyed the traditional categories and concluded that, whenever there is discretionary power and a unilateral undertaking, there is a fiduciary duty; including a fiduciary duty on the Crown. ${ }^{20}$

Three years later, the Supreme Court of Canada was again asked to find a similarly novel fiduciary relationship outside the Indigenous context. In 1987, Frame involved a plaintiff who was intentionally and systematically denied access to his children by his exwife contrary to an initial Family Court order and several subsequent court orders. Justice La Forest, writing for the majority, did not see Justice Dickson's reasons in Guerin as

\footnotetext{
18 Ibid.

19 The English Judicature Acts of 1873 and 1875 combined the Court of Chancery and the common law courts to enable disputed matters to be fully determined without the possibility of double, sometimes conflicting, judgment. Academics and judges have debated whether the merger was substantive or merely procedural. That debate is outside the scope of this paper and is only tangentially addressed insofar as this paper defends the Supreme Court of Canada's current approach to combining equitable and common law concepts in its treatment of the fiduciary concept.

${ }^{20}$ Guerin, supra note 2 at 384-87.
} 
changing the jurisprudential landscape beyond the Indigenous context: he refused to recognize a fiduciary duty, saying it would generate needless and uncertain litigation. ${ }^{21}$

In dissent, Justice Wilson saw that the Court's preoccupation with certainty was causing rightful fiduciary relationships to be unjustly ignored. She provided a nowinfamous "rough and ready" guide to recognizing fiduciary duties which involved the application of three indicia: discretionary power of the fiduciary, unilateral discretion of the fiduciary to use that power to affect the beneficiary's interests, and peculiar vulnerability of the beneficiary. ${ }^{22}$ Two years after Frame, the indicia-based method for finding novel fiduciary relationships was adopted by a 3-2 majority of the Supreme Court of Canada in LAC Minerals Ltd v International Corona Resources Ltd. ${ }^{23}$

Lac Minerals centred on the contested ownership of a mineral-rich property in Northern Ontario. International Corona, a junior mining company, was investigating the property in question and entered discussions with Lac Minerals, a senior mining company, regarding financing and development options with respect to the property. In the course of those discussions, Lac Minerals received detailed, private information regarding International Corona's findings. Lac Minerals advised Corona to pursue the property in question but proceeded to stake its own claim to the property. Corona subsequently formed a joint venture and sued Lac Minerals for the return of the property. $^{24}$

The majority found that the relationship of trust and confidence that had developed between International Corona and Lac Minerals satisfied the indicia from Justice Wilson's so-called rough and ready guide. ${ }^{25}$ However, the majority also emphasized that fiduciary obligations will rarely be generated in commercial relationships ${ }^{26}$ - and, in a concurring judgment, Justice Wilson helpfully clarified that, in her view, the duty only arose when Corona was placed in a position of vulnerability and trust that is rarely found in sophisticated arm's length negotiations. ${ }^{27}$ Thus, in the same

\footnotetext{
${ }^{21}$ Frame, supra note 5 at para 18.

${ }^{22}$ Ibid at para 60.

${ }^{23}$ Lac Minerals Ltd v International Corona Resources Ltd, [1989] 2 SCR 574 [Lac Minerals].

${ }^{24}$ Ibid at paras 115-16.

${ }^{25} \mathrm{Ibid}$ at paras 28, 58 .

${ }^{26}$ Ibid at para 60 .

${ }^{27}$ Ibid at para 89.
} 
breath with which she gave life to the ad hoc approach, Justice Wilson perhaps attempted to pre-empt the concerns and criticisms of commercially-inclined critics such as Duggan. This was, of course, unsuccessful.

Indeed, the Lac Minerals decision was equally unsuccessful at ending the Supreme Court of Canada's internal struggle with certainty and equity. Canson Enterprises Ltd v Boughton \& $\mathrm{Co}^{28}{ }^{28} 1991$ decision dealing with an uncontroversial per se fiduciary relationship, saw the Court split 5-4 over how the battling philosophies regarding such relationships should influence the remedy. Canson was scammed by its lawyer into overpaying for a property. Canson held hope of developing the property for a profit, but its contractors negligently destroyed it. Common law remedies were unavailable: the contractors were insolvent and the scammers were protected by the strict doctrine of causation. Canson therefore sought equitable damages against the lawyer for breach of fiduciary duty.

Justice La Forest, writing for the majority, echoed his certainty-driven philosophy from Frame in rejecting the possibility of equitable damages. He underscored that allowing different redress under common law and equity would breed uncertainty and inefficiency. ${ }^{29}$ In the minority, Justice McLachlin (as she then was) wrote that the equitydriven purpose of fiduciary law requires that equitable remedies be awarded in certain circumstances where the certainty of the common law is deficient. However, she denied equitable damages to Canson. While she stressed that common law standards of foreseeability and remoteness do not apply to fiduciary law, she found that "on a common sense view of causation", the scammer could not be held responsible for the contractors' negligence. ${ }^{30}$

Justice McLachlin's dissent reflects, in many ways, the central contention of this paper. She understood the need for a balance between certainty and flexibility in modern day equity. While she did not deny the role that equitable remedies must play in a robust and fair legal system, she also saw that unbridled equity inevitably turns against itself: her reasons reveal a recognition that it would not be fair to force a small-time scammer

${ }^{28}$ Canson Enterprises Ltd v Boughton \& Co, [1991] 3 SCR 534, [1991] SCJ No 91 (QL) [Canson].

${ }^{29} \mathrm{Ibid}$ at paras $78,87-88$.

${ }^{30} \mathrm{Ibid}$ at paras $28-30$. 
to pay for exponentially more damage than they caused, or for which they would ordinarily be liable. ${ }^{31}$ By applying a diluted standard of certainty to fiduciary law, Justice McLachlin attempted to address Justice La Forest's concerns while still preserving equity's historic role as a gap-filler of the common law's deficiencies.

Justice McLachlin's dissent fell silent, however. In the 1994 Supreme Court of Canada decision Hodgkinson $v$ Simms, ${ }^{32}$ Justice La Forest won another thin majority, this time inexplicably abandoning certainty for a prioritization of free-floating equity. Hodgkinson, a stockbroker seeking tax sheltering advice, hired Simms, an accountant who specialized in that area. Simms recommended that Hodgkinson invest in real estate. Unbeknownst to Hodgkinson, Simms's advice was prejudiced by a covert prearrangement that granted him kickbacks from the investment. The real estate market declined shortly after Hodgkinson's investment. Hodgkinson brought an action for breach of fiduciary duty in an attempt to recover his losses. ${ }^{33}$ The ad hoc approach was called on to determine if there was, in fact, a fiduciary relationship.

Justice La Forest was quick to find that Simms owed Hodgkinson a fiduciary duty. He rejected the common law-focused decision in Canson by emphasizing that "the existence of a contract does not necessarily preclude the existence of fiduciary obligations between the parties" and went on to rationalize fiduciary law according to its historical, equitable justification. ${ }^{34}$ Echoing the Courts of Chancery, he wrote that the underlying purpose of fiduciary law may be seen as protecting and reinforcing "the integrity of social institutions and enterprises", recognizing that "not all relationships are characterized by a dynamic of mutual autonomy, and that the marketplace cannot always set the rules."35

Most importantly, not only did Justice La Forest embrace the indicia-based, ad hoc framework that he had rejected in Frame for being too uncertain, he also applied the Frame indicia very flexibly. For instance, while he properly recognized unilateral discretion as one of the indicia, he suggested that relationships of unilateral discretion are merely one species of fiduciary relationship. He reasoned that, ultimately, broad

\footnotetext{
${ }^{31}$ Ibid at paras 85-87.

323 SCR 377, 117 DLR (4th) 161 [Hodgkinson].

${ }^{33}$ Ibid at 398.

${ }^{34}$ Ibid at 407.

${ }^{35}$ Ibid at 422 .
} 
principles like "[d]iscretion, influence, vulnerability, and trust" can be wielded to recognize fiduciary duties where the fiduciary has some power, but not unilateral discretion, over the beneficiary. ${ }^{36}$ As a whole, Justice La Forest's decision reflects a pivot from a certainty-driven analysis to a highly flexible one.

In dissent, Justice McLachlin (as she then was) once again stressed that the modern jurisprudential and societal landscape requires a balance of certainty and equity. ${ }^{37}$ However, unlike her dissent in Canson, which dealt with a per se fiduciary relationship, this time Justice McLachlin was able to apply her philosophy to the ad hoc approach. While she recognized that the principles of trust and confidence are important, she warned against the uncertainty that Justice La Forest's softening of the unilateral discretion indicia would create. ${ }^{38}$ Justice McLachlin's dissent explicitly references the value of certainty as being necessary to protect basic equity (basic, underived Aristotelian fairness) in the legal system. She wrote: "The difficulty lies in determining what measure of confidence and trust are sufficient to give rise to a fiduciary obligation. An objective criterion must be found to identify this measure if the law is to permit people to conduct their affairs with some degree of certainty." 39 Instead of allowing any degree of vulnerability to create a fiduciary relationship, Justice McLachlin suggested that a fiduciary relationship should require "total reliance by the beneficiary" or that the beneficiary was "at the mercy of the fiduciary's discretion." 40

Justice La Forest retired from the Court soon after Hodgkinson was decided. This did not stop disagreement within the Court, however. The next battleground was the 2007 Supreme Court of Canada decision Strother v 3464920 Canada Inc. ${ }^{41}$ Strother, like Canson, focused on lawyer-client fiduciary relationships (i.e. a type of per se relationship), not ad hoc relationships. Once again, there were clear differences in the preferred fiduciary law philosophies among the Court. The major issue dividing the Court was whether the termination of a retainer ended Strother's fiduciary obligations to his

\footnotetext{
${ }^{36} \mathrm{Ibid}$ at 409.

${ }^{37}$ Ibid at 465-66.

${ }^{38}$ Ibid.

${ }^{39}$ Ibid at 465.

${ }^{40} \mathrm{Ibid}$ at $472-73$.

${ }^{41} 2007$ SCC 24 [Strother].
} 
client. The Court could not have been more diametrically divided. Justice Binnie, writing for the majority, acknowledged that having a retainer creates lawyer-client fiduciary duties, but emphasized that the retainer does not determine the content of those duties. ${ }^{42}$ Justice Binnie's decision is capped by the following powerfully anti-contract determination:

The solicitor-client relationship thus created is, however, overlaid with certain fiduciary responsibilities, which are imposed as a matter of law...fiduciary duties provide a framework within which the lawyer performs the work and may include obligations that go beyond what the parties expressly bargained for. The foundation of this branch of the law is the need to protect the integrity of the administration of justice. ${ }^{43}$

As far as it is possible to compare the essence of Justice Binnie's judgment to previous judgments dealing with the ad hoc approach, it was consistent with Justice La Forest's Hodgkinson decision. Justice Binnie seemed content to keep a somewhat undefined, principle-driven approach to fiduciary law. Both judgments maintained that common law principles cannot colonize fiduciary law so as to determine whether a fiduciary duty is created and how far it extends.

Chief Justice McLachlin argued in dissent that contracts such as retainers should not only create, but also shape fiduciary obligations. ${ }^{44}$ In a powerful statement, she suggested that the fiduciary concept should be moulded to the contract, not vice versa: "The duty of loyalty is not a duty in the air. It is attached to the obligations the lawyer has undertaken pursuant to the retainer. It is not conflict of loyalties in the abstract that raises problems, but conflicting duties - duties that are determined by the retainer." 45 Ultimately, the Chief Justice gave total precedence to market forces, and perhaps implied that fiduciary obligations are consensual, not imposed.

\section{iii. Galambos v Perez}

Two years after Strother saw the Supreme Court of Canada split over competing philosophies, all nine justices unanimously signed onto the remarkably balanced Galambos decision, which has endured as the leading decision on ad hoc fiduciary

\footnotetext{
42 Ibid at para 34.

${ }^{43}$ Strother, supra note 41 at para 34.

${ }^{44}$ Ibid at paras $136-42$.

${ }^{45} \mathrm{Ibid}$ at para 135.
} 
relationships for over a decade. ${ }^{46}$ In Galambos, the plaintiff, Ms. Perez, was the office manager at a struggling Toronto law firm that ultimately went bankrupt. Mr. Galambos, the defendant, was the owner of the firm. As the firm started to struggle, Ms. Perez repeatedly made deposits from her personal account into the firm's account. Mr. Galambos did not directly advise her to do so, and, upon discovering the deposits, advised her to reimburse herself with interest. Ms. Perez ignored him. When the firm went bankrupt, the rigid statutory bankruptcy framework prevented Ms. Perez from recovering. Breach of fiduciary duty was among the actions that Ms. Perez brought against Mr. Galambos. $^{47}$

The Supreme Court of British Columbia, British Columbia Court of Appeal, and Supreme Court of Canada each declined to approach the case through the lens of a per se, lawyer-client fiduciary relationship. Each court agreed that while Ms. Perez had at one point been provided one-off legal services by a lawyer at the firm, her relationship with Mr. Galambos was not, at the relevant times, a lawyer-client one that imposed a fiduciary duty. ${ }^{48}$ As this case wound its way through the court system, the ad hoc approach went through numerous analyses.

The trial court made several important findings of fact. Foremost among these was that Ms. Perez was sophisticated and well-experienced in dealing with lawyers, and she was more knowledgeable than Mr. Galambos himself with respect to the firm's finances. The trial judge therefore found that Ms. Perez did not relinquish her decisionmaking power to Mr. Galambos and that there was no meaningful discretion over her interests that he was able to exercise. ${ }^{49}$ At worst, according to the trial judge, Mr. Galambos may have taken advantage of Ms. Perez's good nature "in a passive way". 50

\footnotetext{
${ }^{46}$ While an in-depth analysis of the reason for this consensus is outside the scope of this paper, two points should be noted. First, the facts of Strother, supra note 41, dealt with a very different landscape than those of Galambos, supra note 1. It is much easier to suggest that a lawyer and a sophisticated client should be able to alter the scope of their obligations than to suggest that a contract should be capable of preventing an ad hoc duty from arising at all. Second, it should be noted that, in Strother, supra note 41, the Chief Justice only adopted a contract-based analysis instrumentally (i.e., only because of its value, in her view, to the administration of justice).

${ }^{47}$ Galambos, supra note 1 at para 1.

${ }^{48}$ Perez v Galambos, 2006 BCSC 899 at para 37 [Galambos BCSC]; Perez v Galambos, 2008 BCCA 91 at para 48 [Galambos BCCA]; Galambos, supra note 1 at para 39.

${ }^{49} \mathrm{Ibid}$ at para 46.

${ }^{50}$ Galambos BCSC, supra note 48 at para 62.
} 
On appeal, the decision was overturned. Rightfully tracking the ad hoc approach jurisprudence from the majority judgments in Hodgkinson, the British Columbia Court of Appeal reasoned that a power-dependence relation of any degree can generate a fiduciary relationship if the dependent party is sufficiently vulnerable. Additionally, the Court of Appeal found that Ms. Perez was vulnerable, stating that the trial judge "gave little, if any, consideration to the respondent's role in cultivating a personal relationship of trust with the appellant". 51

Before Galambos was heard at the Supreme Court of Canada, the disagreement between the lower courts revealed the fundamental problem with the flexibility-driven $a d$ hoc approach from Hodgkinson: reasonable people can disagree over loose criteria such as power-dependence and vulnerability. When the jurisprudence is inherently unpredictable, courts will, on certain occasions, punish a party for being in a type of relationship that the party could not have reasonably known they were in. The modern economy is built on quasi-personal, but primarily business-driven relationships that may include elements of power-dependence. This will not be soon to change. If the fiduciary law jurisprudence were to rest at its post-Hodgkinson state of flexible uncertainty, it would ultimately punish Canadians simply for taking part in the economy. In effect, this is not equitable at all. Ultimately, this would undermine the socially and economically significant relationships which are cherished by the fiduciary concept.

Thankfully, the Supreme Court of Canada unanimously overturned the decision of the British Columbia Court of Appeal and, in doing so, moved the jurisprudence decidedly past Hodgkinson, giving fiduciary law a much more workable resting point. The heart of the decision begins with the Court's acknowledgement that, while Justice La Forest in Hodgkinson used the term "power-dependency" to describe fiduciary relationships, power-dependency merely describes certain relationships which may be fiduciary and not grounds for creating ad hoc fiduciary relationships. ${ }^{52}$ The Court continued with the following: "In short, not all power-dependency relationships are fiduciary in nature, and identifying a power-dependency relationship does not, on its own,

\footnotetext{
${ }^{51}$ Galambos BCCA, supra note 48 at para 55.
}

52 Galambos, supra note 1 at paras 72-73. 
materially assist in deciding whether the relationship is fiduciary or not." ${ }^{53}$ Ultimately, the Court settled on two indicia of ad hoc fiduciary duties: discretionary power of the fiduciary to affect the beneficiary's legal or vital practical interests; and an express or implied undertaking of loyalty. ${ }^{54}$

The discretionary power indicia are a linguistic return to Frame with an important substantive clarification. In the years immediately following Frame, scholars such as Tamar Frankel were quick to interpret discretionary power as a placeholder for abstract considerations like vulnerability and power-dependency. ${ }^{55}$ Justice La Forest was less explicit than Frankel but seems to have reasoned similarly in Hodgkinson. In Galambos, however, the Court took measures to avoid another slippery slope by noting that vulnerability is a misleading analytical marker because it is only a relevant vis-à-vis the relationship, not in and of itself. ${ }^{56}$ In doing so, the Court recognized that considerations of "vulnerability" and "power-dependency" writ large only artificially enlarge the scope of analysis to include irrelevant information. ${ }^{57}$ Ultimately, however, despite being tightened to exclude irrelevant considerations, the discretionary power indicia remain a vehicle for the historical, equitable function of the fiduciary concept once expressed by the Court of Chancery (i.e., safeguarding socially important relationships from abuse related to power imbalance).

The undertaking of loyalty indicia is a certainty-driven counterbalance to the first indicia. It signifies that, regardless of the discretionary power that a would-be fiduciary may hold, fiduciary duties will only be triggered when the would-be fiduciary knew or

${ }^{53} \mathrm{Ibid}$ at para 74.

${ }_{55}^{54} \mathrm{Ibid}$ at paras 69-70.

${ }^{55}$ Frankel, supra note 8 at 810.

${ }^{56}$ Galambos, supra note 1 at paras 67-68.

${ }^{57}$ See Remus Vaslan, "Fiduciary Duties, Conflict of Interest, and Proper Exercise of Judgement" (2016) 62:1 McGill LJ 1 at 8 which is perhaps the leading commentary on Galambos, supra note 1. Vaslan took this observation one step further and argued that the discretionary power indicia should apply only to relationships predicated on the fiduciary promoting the best interests of the beneficiary, not relationships with just any discretionary authority. Vaslan's interpretation of the modern fiduciary concept is, in many ways, in-line with the view advocated for in this paper; however, Vaslan relies too much on the discretionary power indicia for its content. The undertaking indicia is required to separate relationships sufficiently predicated on the beneficiary's best interests from those that are not. It is this paper's contention that the indicia from Galambos, supra note 1, are counterbalances that must be given equal analytical weight. 
ought to have known that they were undertaking to serve the beneficiary's best interests. Unlike the first indicia, the requirement of an undertaking is out of sync with the historical foundation of the fiduciary concept. However, it recognizes what Chief Justice McLachlin had been at pains to make clear for decades: the historical foundation of equity is self-contradictory in the context of a certainty-driven modern society, because it will inequitably punish unknowing parties. Crucially, however, because of the possibility for implied undertakings and the preserved principle from Strother and Hodgkinson that fiduciary duties cannot be altered by contract, the Galambos decision gives credit to the Chief Justice's ideas without going so far as her contract-based Strother dissent.

After decades of turbulence, the Galambos decision remains a workable middle ground and an ideal resting point for Canadian fiduciary law. However, it is necessary to acknowledge the secondary importance of Alberta $v$ Elder Advocates of Alberta Society, ${ }^{58}$ a unanimous 2011 Supreme Court of Canada decision. Elder Advocates was the product of a class action initiated by approximately 12,000 residents of Albertan long-term care facilities against the provincial government. The residents alleged that their mandatory contributions were artificially increased in order to subsidize expenses that ought to have been borne by the government and claimed that Alberta owed a fiduciary duty to ensure that charges were fair and in the best interests of the residents.

Writing for the Court, Chief Justice McLachlin rejected the fiduciary duty plea. She reasoned that the need for the government to act in the interests of society as a whole naturally opposes the supposition that a defined person or class of persons are particularly vulnerable to the exercise of discretionary power. ${ }^{59}$ The approach from Galambos was substantively adopted but the discretionary power indicia was bifurcated, resulting in a reformulation of the Galambos framework as three indicia rather than two. ${ }^{60}$ The commentary on Elder Advocates suggests this was not a substantive departure. ${ }^{61}$ It did not alter Galambos, but rather reinforced it by highlighting that the indicia-based ad hoc

\footnotetext{
582011 SCC 24 [Elder Advocates].

${ }^{59}$ Ibid at para 49.

${ }^{60} \mathrm{Ibid}$ at paras 32-34.

${ }^{61}$ See e.g. Rotman, "Placing Law into Context", supra note 8 at 291, 295; Brent Johnston and Eileen Patel, "Fiduciary Duties and Public Authorities Two Years after Alberta v Elder Advocates: Where Are We Now?" (2013) Continuing Legal Education Society of British Columbia Materials at 5.1.5.
} 
analysis is not merely a step-by-step formula but a context-driven exercise that is in part a reflection of equitable principles.

\section{THE CONTRACT-BASED CHALLENGE}

Contract-based scholars describe themselves as seeing fiduciary law through a functionalist lens, which means it is immaterial to them that fiduciary obligations are not contractual in origin or that, historically, the fiduciary concept stems from a different court system than that of contract law. What matters is the practical role fiduciary law plays today. According to Duggan, that role is to limit self-interested behaviour - the same role that contract law has played for centuries. ${ }^{62}$ The crux of the contract-based argument appears to simply be that, if fiduciary law and contract law have the same function, then the former should not contradict the latter. ${ }^{63}$ If there is a contract between the fiduciary and beneficiary, no fiduciary duties should be inconsistent with the terms of that contract. If duties are ever implied, they should be implied according to what the parties would have bargained for in a reasonable, commercially-efficient agreement. ${ }^{64}$

American scholars Frank Easterbrook and Daniel Fischel stated: "the duty of loyalty is a response to the impossibility of writing contracts completely specifying the parties' obligations."65 Rather than a facts-based, multi-factored, ad hoc approach, contract-based scholars like Duggan would prefer a single analytical vector: What did the parties contract into, or intend to contract into? The contract-based position is not just inconsistent with Galambos; it is inconsistent with the entire modern approach to ad hoc duties which began in Frame. Ultimately, Duggan argues that the modern era of fiduciary law should, and will, give way to a contract-based fiduciary law jurisprudence.

\section{i. The Trend of the Jurisprudence in Canada}

Notwithstanding the Supreme Court of Canada's majority decision in Strother and its initiation of the discretionary power indicia in Galambos - which Duggan calls a

\footnotetext{
62 Duggan, "Primacy of the Deal", supra note 7 at 285.

${ }^{63}$ Ibid at 286-87.

${ }^{64}$ Duggan, "Fiduciary Obligations", supra note 7 at 463-64.

${ }^{65}$ Frank H Easterbrook and Daniel R Fischel, "Contract and Fiduciary Duty" (1993) 36 JL \& Econ 425 at 426.
} 
"substitute" of "one indeterminate indication for another" 66 - Duggan maintains that Canada's more recent, impactful fiduciary law decisions are trending towards being based in contract-like principles. For instance, Duggan argues that, in Strother, the dissent endorsed what was essentially a contract law analysis, whereas the majority merely interpreted the retainer as a question of fact. ${ }^{67}$ Similarly, he contends that Galambos is a "positive development" for contract-based fiduciary law overall because its undertaking indicia "settles the point that a person cannot be made a fiduciary against his will". ${ }^{68}$

However, Duggan's interpretations of Strother and Galambos are unfoundedly optimistic. For instance, Duggan ignores that the Strother majority decided, in obiter, to make the substantive, decidedly anti-contract-based determination that contracts are "overlaid with certain fiduciary responsibilities" which are "imposed as a matter of law". ${ }^{69}$ Clearly, for the majority, contracting intentions were not determinative of fiduciary duties.

Duggan's hailing of the undertaking indica in Galambos' as a victory is similarly overstated. His semantics are misleading. Even on the strictest interpretation of the undertaking indicia, the fiduciary does not get to choose whether to become a fiduciary, only whether to willingly enter into a protected relationship. ${ }^{70}$ First, a person cannot have their cake and eat it too: if a person knowingly enters into power-dependent relationships, they may in fact become a fiduciary against their will. Second, the reserved possibility of implied undertakings ensures that a person will only be able to avoid entering into fiduciary relationships against their will if they act cautiously and are careful to avoid certain relationships. ${ }^{71}$ Ultimately, Duggan thinks that the undertaking indicia leaves much more to the fiduciary's autonomy than it actually does.

Moreover, and most importantly, predictions about a contract-based fiduciary law's future in Canada must be grounded in more than simply the last decade of jurisprudence. Part II of this paper demonstrated that the era of Canadian fiduciary law

\footnotetext{
${ }^{66}$ Duggan, "Fiduciary Obligations", supra note 7 at 463.

${ }^{67}$ Ibid.

${ }^{68} \mathrm{Ibid}$ at 458.

${ }^{69}$ Strother, supra note 41 at para 34.

${ }^{70}$ See e.g. Galambos, supra note 1 at para 77.

${ }^{71} \mathrm{Ibid}$ at paras 70-80.
} 
borrowing most closely from contract-based philosophies has come and gone. The majority judgment in Frame featured Duggan's brand of certainty-driven, common law dominant legal reasoning. Canson, which closely followed Frame, was resolved with the same kind of certainty-driven thinking. As the pendulum of fiduciary law swung to become more equity-focused and liberal, it produced decisions like Hodgkinson. The more recent tandem of decisions in Strother and Galambos are examples of the pendulum finding its middle ground resting point, not another violent swing.

\section{ii. The Substantive Merits of the Contract-Based Fiduciary Law and the Value of Certainty}

Like many functionalist justifications, the contract-based argument is valid but unsound. It is true that fiduciary law functions collaterally to limit self-interest; however, its broader moral ambition is to protect the integrity of socially-important, power-imbalanced relationships. This was true when fiduciary law was governed by the Court of Chancery, and the Supreme Court of Canada clarified in Galambos that it is still true today.

For instance, as discussed in Part II of this paper, since its inception in Keech, the fiduciary concept has been focused not only on preventing wrongful action, but on removing any incentive for wrongful action. ${ }^{72}$ Approximately three-hundred years later, in Galambos, the Supreme Court of Canada still maintained that "underpinning all of this is the focus of fiduciary law on relationships." 73 Ultimately, if the purpose of fiduciary law is to protect fiduciary relationships, and if a relationship is about more than the collective autonomy of two individuals (history, timing, place, etc. are all defining features), then it follows that the purpose of fiduciary law would be undermined by allowing individuals to contract over whether they ought to be subject to fiduciary duties. Essentially, since fiduciary law is more than its function, contract-based functionalism does not support or improve fiduciary law, it undermines it.

Once one recognizes the disingenuousness of asserting that fiduciary law is only about limiting self-interest, the contract-based position is revealed for what it truly is: a

\footnotetext{
${ }^{72}$ Keech, supra note 17.

${ }^{73}$ Galambos, supra note 1 at para 70.
} 
partly circular, partly policy-driven call for fiduciary law to become only about limiting self-interest - to leave behind its equitable origins and become a creature of certainty. Clearly, this is an entirely different argument, one which is out of sync not only with the foundations of the fiduciary concept, but also with the values of Canadian business law statutes and the Canadian Charter of Rights and Freedoms (which enshrine mandatory fiduciary duties and the protection of vulnerable parties through substantive equality respectively). ${ }^{74}$

Crucially, the promotion of that brand of certainty is fundamentally different than that for which I advocate in this paper, not simply in degree, but in kind. In this paper I have argued that some departure from the fiduciary concept's historical, flexible application is necessary in the modern context. However, unlike Duggan, I have not advocated for certainty for its own sake, nor for the sake of the market, at least not directly. To the contrary, I have advocated for certainty for the sake of equity. I have acknowledged that in a society where reasonable people stand the chance of unknowingly entering into relationships that could loosely be characterized as fiduciary, certainty is required to prevent the equitable nature of the concept from self-contradicting. Too much flexibility will lead to arbitrariness, undermining public confidence in the rule of law and disrupting the very relationships in which the law of fiduciary obligations is designed to protect. In the absence of clear rules, parties will be reluctant to enter into any arrangements at all for fear that they will become subject to surprise fiduciary obligations. Certainty ought to be introduced only as necessary to prevent this reality and to preserve the historical function of the fiduciary concept, not to transform the concept as Duggan suggests.

\section{THE ARGUMENT FROM EQUITY}

Contrary to Duggan and other contract-based fiduciary law scholars, Rotman recognizes the fiduciary concept's purpose. He has repeatedly acknowledged that

\footnotetext{
${ }^{74}$ Part I of the Constitution Act, 1982, being Schedule B to the Canada Act 1982 (UK), 1982, c 11, s 15 [Charter]. The Supreme Court of Canada has long settled that section 15 of the Charter, which guarantees rights to equality, is a tool for substantive equality (i.e. protecting socially disadvantaged, vulnerable parties), not formal equality.

For the inconsistency with business law statutes, see e.g. Canada Business Corporations Act, RSC $1985 \mathrm{c}$ C-44, s 122(1)(a)-(b) which imputes statutory fiduciary duties to corporations and their directing minds. See also Andrews v Law Society of British Columbia, [1989] 1 SCR 143.
} 
fiduciary law is meant to protect socially important, power-imbalanced relationships from abuse. ${ }^{75}$ He argues, however, that such an equitable purpose should only be sought with the theory-driven, somewhat undefined equitable principles of the old English Court of Chancery, which he views as more readily able to "account for the idiosyncrasies of individual human interactions". ${ }^{76}$

This paper challenges Rotman's thesis in two respects. First, insofar as Rotman explicitly acknowledges that the fiduciary concept is derivative of equitable principles, he should endorse change to the concept if it is necessary to preserve the broad purpose of equity itself. Second, insofar as Rotman explicitly acknowledges that the advantage of a flexible, loosely-applied fiduciary law is its ability to account for idiosyncratic human interactions, he should concede that, if the Galambos indicia are equally able in this respect, they are not inherently less desirable.

\section{i. The Inequity of an Equity-Dominant Fiduciary Law}

Rotman maintains that if fiduciary law is not sufficiently flexible, its equitable purpose of protecting relationships will be compromised. However, one cannot speak of fiduciary law's "equitable purpose" in isolation from equity itself. As noted in Part II of this paper, equitable principles were not invented entirely by the Court of Chancery. They were derived from philosophical ideas of natural justice. Howard Oleck, who was prolific on the subject of equity, called attention to this by quoting an observation of Sir John William Salmond: “[In] England the term 'equity,' means either natural justice or that particular branch of English law which was developed and applied by the Court of Chancery ... English speech conceals the connection between them"77. Oleck, attempting to underscore the circularity of crediting the so-called "courts of equity" with inventing equity itself, wryly commented that Salmond's latter description of equity "is hardly a definition". 78

Equity as it applies to the law has always been a proxy for moral ideals, specifically fairness. The fiduciary concept was extremely flexible when it was applied

\footnotetext{
${ }^{75}$ Rotman, "Understanding Fiduciary Duties”, supra note 8 at 976.

${ }^{76}$ Ibid at 988.

${ }^{77}$ Howard L Oleck, "Historical Nature of Equity Jurisprudence" (1951) 20:1 Fordham LR 23 at 24-25.

${ }^{78}$ Ibid.
} 
by the Court of Chancery because at the time, equity was needed to align English common law with English morality. English society was dominated by an unreasonably strict and inflexible common law at the time. This is not the case in Canada today.

If the Court of Chancery's use of equity as a flexible tool to soften the harshness of common law is not truly equity, but merely a manifestation of equity in eighteenthcentury England, then we must acknowledge that equity's modern application is an open question. Natural justice in Canada, a core moral value, reflects more than a need for flexibility. Throughout its history, Canada has rejected American individualism for the collective; however, since the advent of the Charter, it has also signalled that it has a robustly rights-based society as well. It is important for the fiduciary concept to focus on the relationships that bind the collective and undergird social cohesion; but that focus cannot be so narrow that it completely forgets basic individual justice. Modern equity and the fiduciary concept should still demand flexibility and a correlative degree of vagueness, but they should not punish unknowing parties who, in the name of the modern economy, are forced to enter relationships at the margins of the fiduciary concept. As the Supreme Court recognized in Galambos, the fiduciary concept must cede some flexibility to the certainty of common law.

\section{ii. The Galambos Indicia and idiosyncratic Relationships}

Rotman challenges the Galambos indicia, and particularly the undertaking indicia, for being unable to catch all forms of fiduciary relationships. ${ }^{79}$ While a degree of under-recognition can be justified for the sake of certainty, Rotman's critique of the Galambos indicia has other problems.

Firstly, it is based on a misunderstanding of the undertaking indicia. Rotman has argued that many relationships that are fiduciary in nature have no undertaking (actual or implied). He reasoned that these relationships will either go unrecognized or the Court will have to turn to a fictitious implied undertaking to justify finding a relationship. Therefore, there is either an under-recognition of fiduciary duties, or the implied undertaking indicia is a proxy for undefined equitable principles. ${ }^{80}$ The former is a

\footnotetext{
${ }^{79}$ Rotman, "Placing Law into Context", supra note 8 at 287-88.

${ }^{80} \mathrm{Ibid}$ at 291, 295.
} 
disservice to fiduciary law and the latter is simply Rotman's approach dressed up with false certainty. To summarize in his own words, Rotman argues: "the implied undertaking fashioned in Galambos should be abandoned if the purpose behind its creation was to have the existence of an undertaking support... ideas of certainty". ${ }^{81}$

However, Rotman's argument is predicated on a false dichotomy. While it is true that the implied undertaking indicia could easily be subject to abuse, implied undertakings do exist in reality. Rotman ignores this obvious reality. He ignores that the objective conduct of a fiduciary party could truly reflect a subjective, knowing willingness to enter into a power-dependence relationship. The examples that Rotman uses to attack the artificiality of the implied undertaking indicia demonstrate this. For instance, he writes:

Fiduciary obligations may also arise in the absence of proof of intention, such as where one party's actions bring about fiduciary responsibility, or where no thought had been given to intention at all. One example of the latter situation exists where a partnership is found by the courts based on the parties' interaction in circumstances where they had not turned their minds to the legal characterization of their relationship. ${ }^{82}$

Conversely, the fact that the parties did not turn their minds to the legal characterization of their relationship does not mean that they did not impliedly undertake fiduciary duties. In Galambos, the Court made it clear that the undertaking need not be in respect to specific legal obligations, but merely "that the fiduciary will act in the best interests of the other party." 83 This is exactly the kind of inexplicit promise that business partners often make to each other. If a court were to impute fiduciary duties to the partners, it would be using the implied undertaking in a fact-based manner, not as an empty policy vehicle. Rotman's observations about the implied undertaking indicia demonstrate the need for a rigorous, fact-driven application, but they do not reveal inherent weakness in the concept.

Moreover, Rotman's criticism of the Galambos indicia fails to acknowledge that the approach for which he advocates, an abandonment of indicia altogether in favour of loose principles, would bring the opposite problem: a false over-recognition of novel

\footnotetext{
${ }^{81} \mathrm{Ibid}$ at 288.

${ }^{82}$ Ibid.

${ }^{83}$ Galambos, supra note 1 at para 66.
} 
fiduciary duties. Rotman's approach would require the repeated use of deductive reasoning (i.e. top-down reasoning from axiomatic principles) in each instance where a potentially novel fiduciary duty was argued. Since fiduciary law's axiomatic principles are inherently vague, deduction from those principles would be similarly vague and inconsistent.

The ad hoc, indicia-based approach avoids this problem because it is based on inductive reasoning. Justice Wilson did not create the Frame indicia with abstract philosophizing, but by rigorously surveying the per se fiduciary duties and identifying common elements. Galambos is doubly inductive: it reasons not only from the Court's list of per se duties, but also from its decades of successes and failures with the ad hoc approach. Fiduciary law is frustratingly vague. While Rotman's desire for a neat, deductive unpacking of the concept is understandable, the unfortunate reality is that such attempts will not "solve the concept", but rather will only generate uncertainty. As this paper has argued, those uncertainties in turn produce inequities that self-contradict the philosophical basis for the concept itself.

\section{CONCLUSION}

Through a rebuttal of the writings of fiduciary law scholars Anthony Duggan and Leonard Rotman, I have argued that the Galambos indicia are sufficiently comprehensive and certain to overcome popular academic criticisms of the indicia-based ad hoc approach. In doing so, I have uncovered and explored a striking paradox about equity in the modern context, at least as it relates to fiduciary law. While legal certainty is, in many ways, antithetical to equitable principles, the latter will inevitably self-contradict without some measure of the former. 